\title{
Terrorism, Trust and Tourism
}

\author{
Susanne Jensen \\ Idea2action \\ Houvej 13, DK-9500 Hobro, Denmark \\ E-mail: sus@idea2action.dk
}

Gert Tinggaard Svendsen

Aarhus University, Department of Political Science

Bartholins Allé 7, Building 1350, DK-8000 Aarhus C, Denmark

E-mail: gts@ps.au.dk

Received: November 22, 2017 Accepted: December 12, 2017 Published: December 19, 2017

doi:10.5296/iss.v5i2.12331 URL: http://dx.doi.org/10.5296/iss.v5i2.12331

\begin{abstract}
How does terrorism affect social trust and tourism? The rising number of terrorist attacks in Western Europe has caused safety problems not only for local citizens but also for tourists. In fact, terrorists challenge the formal violence monopoly of the state thus creating a sense of anarchy and distrust. Social trust is about trusting strangers, so when less predictable behaviour occurs in, a given country, people become more careful as they tend to trust most other people less. An interesting case for future research is Scandinavia as the level of terroris $m$ is still low and, at the same time, Scandinavia can record most social trust in the world meaning a competitive advantage when attracting tourists. Arguably, a double dividend is created from fighting terrorism, namely more social trust accumulated and more tourists attracted. Future research should therefore try to further test our model by both quantitative and qualitative methods, for example by undertaking extensive comparative studies between Scandinavia and other countries with more terrorism and less trust.
\end{abstract}

Keywords: Terrorism, social trust, tourism, double dividend, Scandinavia 


\section{Introduction}

Recently, numerous terrorist attacks in Western Europe have caused huge safety problems for the tourism industry and a feeling of fear and danger among tourists when they travel (Jensen \& Svendsen 2016; Kozak et al. 2007; Page \& Connell 2006; Mansfeld \& Pizam, 2006). Motivation has for long been seen as an important topic for tourism research and safety is a driving force for actions (Crompton, 1979; Pearce \& Lee, 2005; Yang et al., 2015). Terrorism implies the arbitrary use of violence causing uncertainty and non-predictable behaviour, a risk factor which tourists have to take into account when travelling abroad. In fact, moving around in the public sphere in another country among strangers is a matter of social trust and the capability of predicting other peoples' behaviour, for example the risk of being attacked in the open street (Svendsen 2014).

The series of four coordinated terrorist attacks on the United States on the morning of Tuesday, September 11, 2001 (also referred to as 9/11) is another example of changing this risk factor by attempting to create anarchy and distrust. President George W. Bush responded to the attack in his "Address to the Nation" and made this statement:

"The pictures of airplanes flying into buildings, fires burning, huge structures collapsing, have filled us with disbelief, terrible sadness, and a quiet, unyielding anger. These acts of mass murder were intended to frighten our nation into chaos and retreat. But they have failed; our country is strong." (White House, 2001).

The literature, however, has not yet dealt with the complex relations between both terrorism, social trust and tourism. Our contribution is therefore to discuss and develop a model linking the social science issues of terrorism and trust to the level of tourism. Thus, the research question we discuss in the remainder of the paper is: How does terrorism affect social trust and tourism? The discussion proceeds in Section 2 with a public good discussion on safety and tourists' motive for choice of destination. Section 3 introduces the issue of trust before Section 4 gives the conclusion and perspectives.

\section{Safety and Tourists' Motive for Choice of Destination}

The presence of safety, as provided by the state, is one of the rare examples of a pure public good (Tietenberg \& Lewis 2012; Hillman 2009). Another classical example could be the state provision of $\mathrm{CO}_{2}$ reduction in order to avoid global warming (Brandt \& Svendsen 2016). Focusing on safety, this issue fulfils both conditions for a public good in a satisfactory way. First condition is non-excludability, meaning that no one can be excluded from benefitting from the good. So, if an extra tourist arrives, it is not possible to exclude him or her from enjoying the current benefits of safety. The second condition is jointness of supply where the entrance of new consumers (such as the tourist) does not affect the quality of the public good of safety. The level of safety will normally remain the same within a typical interval of newcomers. If, however, many people arrive at the same time as has been the case in the current mass migration crisis in Europe, such very high numbers may in itself pose a safety risk, especially when combined with potential terrorist attacks (Chloupková et al. 2016; Franck et al. 2005; Wilks \& Page 2003). 
Furthermore, the so-called 'parallel societies' may pose a future threat to safety if a significant number of immigrants stay outside society with a number of social problems such as unemployment, political radicalization and high crime rates which again will reduce the level of safety (Nannestad et al. 2008; Nannestad et al. 2014). Problems of unsafe parallel societies may here be addressed by specific solutions such as the US government program named "Moving to Opportunity" Here, single mothers were randomly chosen by lottery and: "The mothers could relocate with their families from low-income neighbourhoods with inferior schools to neighbourhoods where schools were better and where there was greater personal safety" (Hillman 2009, 608). Overall, concerning safety, condition two where the good is not crowded out, is normally fulfilled within a reasonable interval of new entrants into a country or neighbourhood, in particular when considering the potential entry of peaceful tourists as is the case in this paper.

Clearly the personal safety motive among tourists may also be influenced by a number of other factors than the very presence of state power and safe streets, such as cultural distance between hosts and tourists, former travel experiences in general, specific travel experiences with Denmark, age of the traveller, types of travel group, types of holiday, and types of destination (Garg 2015). A high cultural distance may imply that tourists are not familiar with the social norms for behaviour and human interaction at the destination they visit (Goeldner $\&$ Richtie 2006). Travelling to neighbouring countries may be a way of managing the distance and the possible hazardous misunderstandings cultural distances may result in.

The estimations will also include dynamic aspects since the time dimension in how experienced tourists are as travellers may influence the decisions taken. Especially when we talk about safety, previous experiences with the destination may be seen as important (Yang et al. 2015). In the tourism literature, for instance, Pearce's travel career ladder and travel career pattern approaches suggest that tourists' motivation changes over their life stages and/or with their travel experiences (Pearce 2005). Thus, it may indeed matter whether tourists have visited the same country before and how many times. Likewise, we include an age variable because younger tourists may - compared to older tourists - engage in more hedonistic activities, often under the influence of alcohol or to higher extent seek novelty compared to familiarity (Page \& Connell 2006; Yang et al. 2015).

Furthermore, the type of travel group may influence whether tourists are motiva ted by safety. Travelling in a family group with children may affect the perceived risks of visiting a destination because you have a responsibility for others than yourself. The type of holiday is related to psychological factors of travelling, where some forms of accommodation resemble being at home more than others (Goeldner \& Ritchie 2006). This is for instance the case with rented holiday homes, which may give a feeling of being at home. Likewise, with camping, where you actually bring your own home to a new place, making it possible to create a homelike atmosphere and, at the same time, explore new destinations. Finally, the type of destination may matter, for instance when some destinations have higher incident rates than others because of urbanisation. 


\section{Social Trust}

Terrorism may lead to more general distrust in a society because people may start trusting strangers less as they are now more likely, paribus ceteris, to be potential terrorists compared to the situation before the terror events. You become more careful and changes behaviour. A crucial argument regarding how such social trust is affected by terrorism depends on whether the terrorist act is repeated or not. If it is repeated, the state seems no longer capable of enforcing its violence monopoly (Fukuyama 2011). In contrast, if the state responds immediately by formal enforcement and solves the problem, the situation is under control and people can move on in the same path as before. In other words, we are small statisticians in everyday life, counting cases and doing risk assessments like the repetition of actions between different player types in game theory (Poulsen \& Svendsen 2005).

Tourists may, for example, bike along the sea without being mugged by the locals. When succeeding in doing this, the involved actors cooperate. If, however, some of the locals repeatedly mug the tourists on bike, i.e. they defect in the terminology of game theory, then the tourists will soon stop cooperating by leaving the area and not come back, i.e. they de fect too. In this way, less win-win situations will occur from voluntary transactions in a given society where the state no longer can enforce its violence monopoly as is the case with terrorism too (Chloupkova et al. 2016). In this way, social trust can be viewed as a positive externality in society when existing as non-written rules that define human behaviour and relations between strangers (Gundlach \& Svendsen, 2017). A high level of social trust implies a high degree of self-regulation based on cooperation norms (Svendsen \& S vendsen, 2016a; Brandt \& Svendsen 2010; Ostrom \& Ahn 2009).

Scandinavia exhibits an interesting case as the number of terrorist attacks experienced have been very few so far. At the same time, contemporary surveys show that the Scandinavian countries (Norway, Sweden and Denmark) by far have the highest levels of social trust in the world, namely all above $70 \%$ in 2009 . Social trust is here measured as the average percentage in a given population confirming that most other people can be trusted. In comparison, about $40 \%$ of the US citizens think that most people can be trusted. Trust in most people means that a local or a tourist is more likely to trust a stranger and start cooperating rather than distrust and defection. In other words, the agents save many resources when they do not need to be cautious and constantly on the watch (Svendsen \& Svendsen 2015).

For example, governments and corporations are gradually increasing their control over people's public and private lives. The costs of more control such as extensive New Public Management systems, are, however, extremely high, and the probable result of its increase is the slow depreciation of a society's trust reserve and less profits. Lenin once said "Trust is good, but control is better," but because the presence of social trust lowers transaction costs in everyday life, perhaps we should instead say "Control is good, but trust is cheaper" (Jensen \& Svendsen 2014). This result also holds both for local citizens but also for tourists when they cooperate and achieve voluntary win-win situations.

Why Scandinavia today holds the most social trust in the world is a big puzzle. It probably takes long time to accumulate such a unique stock of social trust. However, at least two 


\section{Macrothink

special historical features characterize Scandinavia. First, these Scandinavian countries experienced very early state-building and monopolization of violence dating back to Viking age (Svendsen \& Svendsen 2016b). This fits the Fukuyama (2014) argument that power centralisation may be favourable to kick start the building of institutions and well-functioning states such as Denmark is today. In fact, Fukuyama $(2011 ; 2014)$ pursues a goal he calls "Getting to Denmark", a model to be applied throughout the world. Second, corruption was fought efficiently already in medieval times, making social behaviour even more fair and predictable (Frisk Jensen 2013; Teorell \& Rothstein 2012).

\section{Conclusion}

The main research question addressed a discussion on how terrorism affects social trust and tourism. First, Section 2 discussed the public good of safety as one of the main factors in the literature on motivation theory. As terrorism challenges the formal violence monopoly of the state, the level of social trust may deteriorate as social behaviour in society becomes less predictable and distrust in strangers increase. People become more careful - so do tourists, arguably, as they may decide to go to other and safer destinations with less terrorism and more social trust. Repeated terror events in a given country probably affects social trust and the level of tourism negatively. Therefore, a double dividend is coined when fighting terrorism, namely more social trust and more tourists coming in. Scandinavia is an intriguing case due to its special feature of both a low risk of terror attacks and a world record high level of social trust.

Overall, Figure 1 shows the possible causal relationships as touched upon in this paper. In the short run, there is a direct linkage between terror and perceived safety. Even more interesting, however, is that there may be an indirect correlation too through social trust and/or formal enforcement by the state. Also, one may focus on the time horizon as terrorism in the short run can affect both perceived safety and formal enforcement by authorities, while terrorism in the long run will still affect formal enforcement but also social trust. This may affect perceived safety. Thus, terrorism may have both direct and indirect influences on tourists' perception of safety and this effect may be seen both in the short and the long run. 


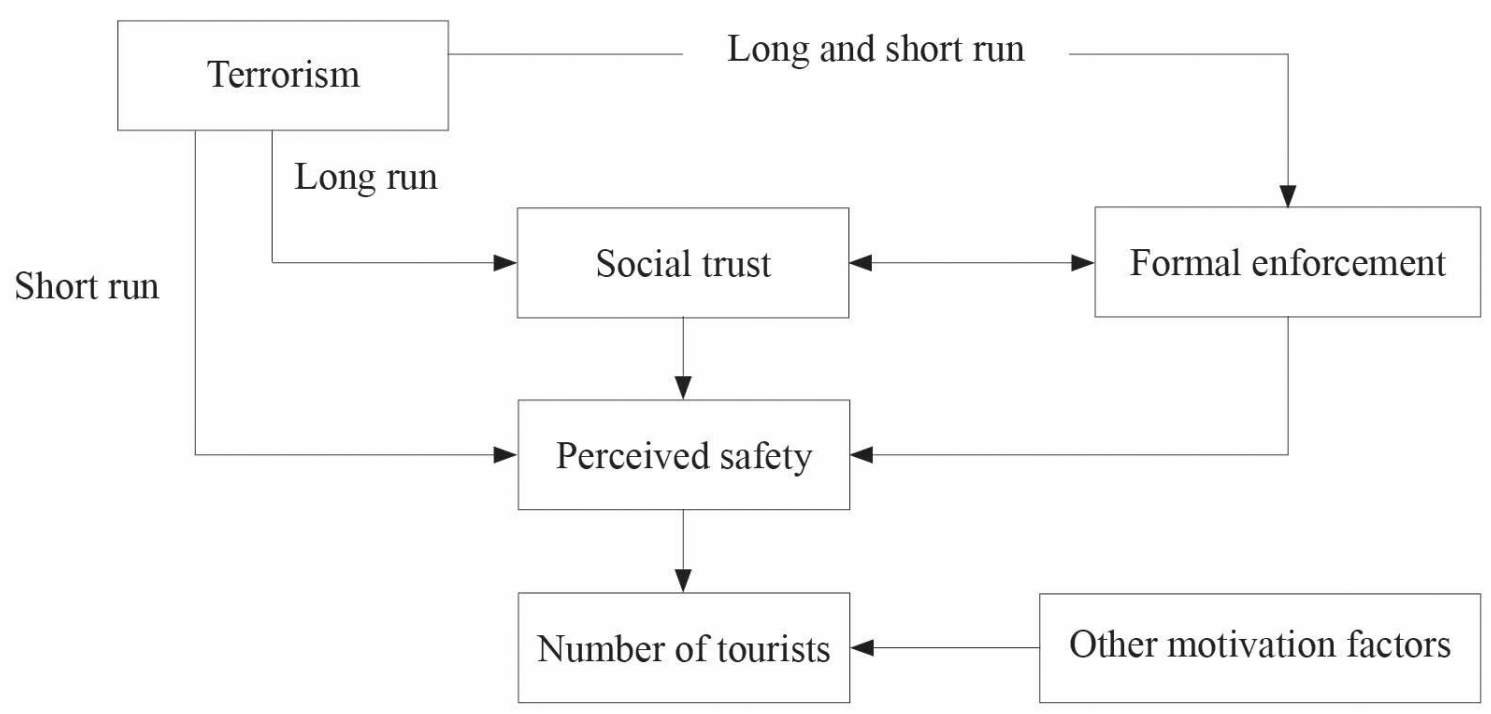

Figure 1. Linkages between terrorism, trust and tourism

One implication of the analysis is that the feeling of safety may be used consciously by tourist managers in their marketing efforts designed to attract tourists. It gives a competitive edge. For example, some of the tourists that attach importance to safety are attractive for Scandinavian tourism to expand its market, i.e. the popular perception of the Nordic states as fairy tale countries could be expanded with the absence of terrorism and the notion of safety for tourists in the streets and elsewhere. This implication applies in general to all countries seeking to enhance the feeling of safety and thereby attracting more tourists. Another implication for tourism is that a high level of self-regulation, i.e. social trust, may be preferable as formal enforcement visibly signals problems with safety. Thus, perceived safety risks are likely to be relatively lower in countries with high scores on social trust.

Overall, future research should try to further explore the potential link between terrorism, trust and tourism in a society undertaking both quantitative and qualitative methods. Such a mixed-method approach could help establishing whether the causal effects suggested in Figure 1 are true or not. Such links may show a promising direction for future research as the need for formal enforcement of safety decreases when informal enforcement based on social trust increases. Comparative studies between Scandinavia and other countries with more terrorism and less trust are thus theoretically bound to be fruitful. 


\section{References}

Brandt, U. S., \& Svend sen, G. T. (2010). The Survival of the Nordic Welfare State and Social Trust. Nordic Journal of Political Economy, 36, 1-15.

Brandt, U. S., \& Svendsen, G. T. (2016). The Politics of Persuasion: Should Lobbying Be Regulated in the EU? Cheltenham. UK: Edward Elgar Publishing.

Chloupková, J., S vendsen. G. T., \& Zdechovský. T. (2016). Do Strategic Foresight and Policy Making Go Hand in Hand? Security in the European Union. Journal of Contemporary Management, 3, 33-41.

Crompton, S.L. (1979). Motivations of Pleasure Vacation. Annals of Tourism Research, 6, 408-424. https://doi.org/10.1016/0160-7383(79)90004-5

Franck, R., Hillman. A. L., \& Krausz, M. (2005). Public Safety and the Moral Dilemma in the Defense against Terror. Defense and Peace Economics, 16, 347-364. https://doi.org/10.1080 $\underline{10242690500207399}$

Frisk Jensen, M. (2013). Korruption og embedsetik: Danske embedsmands korruption $i$ perioden 1800-1866. Odense: University Press of Southern Denmark. (Corruption and the Ethics of Public Office - Corruption among Danish civil servants during the period 1800-1866).

Fukuyama, F. (2011). The Origins of Political Order: From Prehuman Times to the French Revolution. New York: Farrar, Straus and Giroux.

Fukuyama, F. (2014). Political Order and Political Decay: From the Industrial Revolution to the Globalization of Democracy. New York: Farrar, Straus and Giroux.

Garg, A. (2015). Travel Risks vs Tourist Decision Making: A Tourist Perspective. International Journal of Hospitality \& Tourism Systems, 8, 1-9.

Goeldner, C. R., \& Ritchie, J. R. B. (2006). Tourism: Principles, Practices, Philosophies. Hoboken: John Wiley \& Sons.

Gundlach, E., \& Svendsen, G. T. (2017). How Do High and Low Levels of Social Trust Affect the Long-run Performance of Poor Economies? Submitted paper, version 28.04.2017.

Hillman, A. L. (2009). Public Finance and Public Policy: Responsibilities and Limitations of Government. Cambridge: Cambridge University Press.

Jensen, K., \& Svendsen, G. T. (2014). Control Is Good, But Trust Is Cheaper. Forbes. August 12.

Jensen, S., \& Svendsen, G. T. (2016). Social Trust, Safety and the Choice of Tourist Destination. Business and Management Horizons, 1, 1-9. https://doi.org/10.5296/bmh. v4i.9232 
Kozak, M., Crotts, J. C., \& Law, R. (2007). The Impact of the Perception of Risk on International Travellers. International Journal of Tourism Research, 9, 233-242. https://doi.org/10.1002/jtr.607

Mansfeld, Y., \& Pizam, A. (eds.) (2006). Tourism, Security and Safety: From Theory to Practice. Oxford: Butterwoth-Heinemann.

Nannestad, P., Svendsen, G. H. L., \& Svendsen, G. T. (2008). Bridge over Troubled Water? Migration and Social Capital. Journal of Ethnic and Migration Studies, 34, 607-631. https://doi.org/10.1080/13691830801961621

Nannestad, P., Svendsen, G. T., Dinesen, P. T., \& Sønderskov, K. M. (2014). Do Institutions or Culture Determine the Level of Social Trust? The Natural Experiment of Migration from Non-Western to Western Countries. Journal of Ethnic and Migration Studies, 40, 544-565. https://doi.org/10.1080/1369183X.2013.830499

Ostrom E, \& Ahn, T. K. (2009). The meaning of social capital and its link to collective action. In G. T. Svendsen \& G. L. H. S vend sen, Handbook of Social Capital: the Troika of Sociology, Political Science and Economics, 1st ed., Cheltenham, UK, Edward Elgar Publishing Limited, 17-35. https:/doi.org/10.2139/ssrn.1304823

Page, S., \& Connell, J. (2006). Tourism: A Modern Synthesis, UK: Thomson Learning, $2^{\text {nd }}$ edition.

Pearce, P. L. (2005). Tourist Behavior: Themes and Conceptual Schemes. Clevedon: Channel View Publications.

Pearce, P. L., \& Lee, U-I. (2005). Developing the Travel Career Approach to Tourist Motivation. Journal of Travel Research, 43, 226-37. https://doi.org/10.1177/0047287504 272020

Poulsen, A., \& Svendsen, G. T. (2005). Social Capital and Endogeneous Preferences. Public Choice, 123, 171-196. https//doi.org/10.1007/s11127-005-0266-0

Svendsen, G.T. (2014). Trust, Aarhus. Denmark: Aarhus University Press.

Svendsen, G. L. H., \& Svendsen, G. T. (2015). The Puzzle of the Scandinavian Welfare State and Social Trust. Issues in Social Science, 2, 90-99. https://doi.org/10.5296/iss.v3i2.8597

Svendsen, G. L. H \& Svendsen, G. T. (2016a). Trust, Social Capital and the Scandinavian Welfare State: Explaining the Flight of the Bumblebee, Cheltenham, UK: Edward Elgar. https://doi.org/104337/9781785365584

Svendsen, G. L. H., \& Svendsen, G. T. (2016b). How did Trade Norms Evolve in Scandinavia?: Long-Distance Trade and Social Trust in the Viking Age. Economic Systems, 2, 198-205. https://doi.org/10.1016/j.ecosys.2016.03.001

Teorell, J., \& Rothstein, B. (2012). Getting to Sweden: Malfeasance and Bureaucratic Reforms, 1720-1850. QOG Working Paper 2012: 18, Gothenburg. 


\section{Macrothink}

Issues in Social Science ISSN 2329-521X 2017, Vol. 5, No. 2

Tietenberg, T., \& Lewis, L. (2012). Environmental and Natural Resources Economics. UK: Pearson International, 8th edition.

White House (2001). Statement by the President in His Address to the Nation. Office of the Press Secretary, September 11, 2001. https://georgewbush-whitehouse.archives.gov/news/releases/2001/09/20010911-16.html

Wilks, J., \& Page, S. (eds.) (2003). Managing Tourist Health and Safety. Oxford: Elsevier.

Yang, E.C.L., Sharif, S. P., \& Khoo-Lattimore, C. (2015). Tourist' Risk Perception of Risky Destinations: The Case of Sabah's Eastern Coast. Tourism and Hospitality Research, 15, 206-11. https//doi.org/10.1177/1467358415576085 